\title{
High molecular mass forms of epidermal growth factor in pig uterine secretions
}

\author{
D. R. Brigstock ${ }^{1,2,3}$, G. Y. Kim ${ }^{1,2}$, C. L. Steffen ${ }^{1}$, A. Liu ${ }^{1}$, \\ R. K. Vegunta ${ }^{1}$ and N. H. Ismail ${ }^{1}$ \\ Departments of ${ }^{1}$ Surgery and ${ }^{2}$ Medical Biochemistry, and ${ }^{3}$ Molecular, Cellular and Developmental \\ Biology Program, The Ohio State University College of Medicine and Children's Hospital, 700 Children's \\ Drive, Columbus, OH 43205, USA
}

\begin{abstract}
Accumulating evidence suggests that uterine luminal fluids contain a variety of polypeptide growth factors and cytokines that, it is speculated, have roles in the development, growth and differentiation of the uterus and, during pregnancy, in the growth and survival of the embryo. Although epidermal growth factor (EGF) has previously been identified by radioimmunoassay and immunohistochemistry in the pig uterus, there have been no detailed studies of the secreted EGF protein. EGF was therefore purified from uterine flushings and uterine fluids of nonpregnant pigs of mixed breed using a variety of ion-exchange chromatography steps. Uterine flushings and fluids contained an anionic factor(s) that at $4^{\circ} \mathrm{C}$ competed with ${ }^{125}$ I-labelled mouse EGF for binding to EGF receptors on an endometrial carcinoma cell line and stimulated DNA synthesis in Balb/c mouse 3T3 fibroblasts. As analysed by gel filtration, uterine fluids contained a $3-6 \mathrm{kDa}$ factor that stimulated $3 \mathrm{~T} 3$ cell DNA synthesis and was a competitor of cellular ${ }^{125}$ I-labelled EGF binding. Gel filtration further revealed that uterine flushings and fluids contained, respectively, $45 \mathrm{kDa}$ and 40-70 kDa moieties that were mitogenic and that bound to the EGF receptor. SDS-PAGE and western blotting using an antiserum specific for pig EGF revealed immunoreactive forms of EGF of approximately $25 \mathrm{kDa}$ in partially purified uterine flushings. It is concluded that uterine secretory EGF occurs, at least in part, as high molecular mass proteins. The ability of these high molecular mass EGFs to bind to and activate the EGF receptor suggests that they may be authentic ligands for the EGF receptor in utero.
\end{abstract}

\section{Introduction}

Uterine luminal fluids contain a variety of largely undefined constituents that are thought to regulate various aspects of uterine and placental function (Roberts and Bazer, 1988). The pig is a useful model for the study of the role of these factors because its uterus, being very large, is particularly suitable for protein biochemical approaches for studying the constituent growth factors in uterine secretory fluids. Previously, the pig uterus has been shown to produce insulin-like growth factors (IGF-I), fibroblast growth factors (FGF), pleiotrophin, and various members of the epidermal growth factor (EGF) family such as EGF, heparin-binding EGF-like growth factor (HB-EGF), transforming growth factor $\alpha$ (TGF- $\alpha$ ) and amphiregulin (Tavakkol et al., 1988; Brigstock et al., 1989, 1990, 1996; Letcher et al., 1989; Ogasawara et al., 1989; Simmen et al., 1990, 1992; Diehl et al., 1994; Kennedy et al., 1994; Kim et al., 1995). Of these, IGF-I, EGF, HB-EGF, basic FGF and pleiotrophin have been shown to be components of uterine luminal fluids. Although detailed studies of their production and secretion

Received 8 May 1996. during the oestrous cycle and pregnancy are limited to IGF-I (Tavakkol et al., 1988; Letcher et al., 1989; Simmen et al., 1990), the presence of several mitogenic factors in pig uterine fluids suggests interacting autocrine and paracrine pathways through which uterine function is regulated, particularly that of the uterine surface epithelium which is in direct contact with luminal fluids. In addition, the presence of these factors in uterine tissues and fluids suggests that their localization at the attachment site or release into the uterine lumen may represent paracrine mechanisms through which conceptus development is regulated (Brigstock et al., 1994).

EGF occurs at high concentrations $\left(1-1000 \mathrm{ng} \mathrm{ml}^{-1}\right.$ ) in a variety of body fluids (see Carpenter and Wahl, 1991). Accordingly these fluids are a significant reservoir of EGF and are probably an important means by which EGF is delivered to its target cells in vivo. Unfortunately, the lack of homologous probes has severely hampered the study of EGF in the body fluids of pigs. While early studies showed that an antiserum to mouse EGF decreased the stromal cell mitogenic activity of crude pig uterine luminal flushings (Simmen $e t$ al., 1988), only with the cloning and expression of the $6 \mathrm{kDa}$ pig EGF (pEGF) molecule (Pascall et al., 1991) was it possible to develop an 
antiserum to $\mathrm{pEGF}$ for use in a radioimmunoassay that provided clear evidence for the presence of immunoreactive EGF in pig uterine fluids (Vaughan et al., 1992; Diehl et al., 1994). Although additional studies using the reverse-transcriptase polymerase chain reaction (RT-PCR) and immunohistochemistry have verified uterine $\mathrm{PEGF}$ expression and production (Kennedy $e t$ al., 1994), no studies have addressed the molecular structure of the active ligand. Since members of the EGF family are initially synthesized as large precursor proteins that become embedded in the plasma membrane from which the mature growth factor is released by extracellular proteolytic cleavage (Prigent and Lemoine, 1992), there are numerous points in the biosynthesis and processing of EGF that may serve to regulate its bioavailability and specific activity. With the recognition that the extracellular regulation of growth factor structure and function is a key component of growth factor activity and mode of action in vivo (Flaumenhaft and Rifkin, 1992), we have performed a structural and functional analysis of EGF proteins in pig uterine luminal fluids.

\section{Materials and Methods}

\section{Animals}

Uteri were obtained at random from nonpregnant prepubertal and pubertal pigs of mixed breed of up to about 8 months old from a local abattoir. Uteri were transported on ice to the laboratory where the broad ligament was removed. Uterine luminal fluid was collected by allowing each uterine horn to drain under gravity. Uterine horns were then flushed with PBS as described by Kim et al. (1995) and Brigstock et al. (1996). Fluid and flushings were either used immediately or stored at $-20^{\circ} \mathrm{C}$. Samples were centrifuged at $13500 \mathrm{~g}$ for $30 \mathrm{~min}$, and the supernatant passed through glass wool before analysis.

\section{BioRex cation-exchange and heparin-Sepharose affinity chromatography}

Multiple cationic heparin-binding growth factors are present in pig uterine secretions (Brigstock et al., 1989, 1996; Kim et al., 1995). These factors were removed by subjecting the uterine fluid and flushings to cation-exchange chromatography or heparin-affinity chromatography or both processes. Flushings were passed at $2.5 \mathrm{ml} \mathrm{min}^{-1}$ through a BioRex 70 cation exchange column $(2 \times 2.5 \mathrm{~cm}$; Bio-Rad Labs, Richmond, CA) that had been pre-equilibrated with $10 \mathrm{mmol}$ Tris- $\mathrm{HCl} \mathrm{I}^{-1}$, $0.1 \mathrm{~mol} \mathrm{NaCl}{ }^{-1}$ ( $\mathrm{pH}$ 7.4). The flow-through fraction was then passed at $2 \mathrm{ml} \mathrm{min}^{-1}$ through a heparin-Sepharose column $(1.5 \times 2.7 \mathrm{~cm}$; Pharmacia Biotech, Pisactaway, NJ) that had been pre-equilibrated with $10 \mathrm{mmol}$ Tris- $\mathrm{HCl}^{-1}, 0.1 \mathrm{~mol} \mathrm{NaCl} 1^{-1}$ ( $\mathrm{pH}$ 7.4). Uterine fluid was subjected directly to heparin-affinity chromatography after either being diluted tenfold in $10 \mathrm{mmol}$ Tris- $\mathrm{HCl} 1^{-1}(\mathrm{pH} \mathrm{7.4)}$ or mixed with one-tenth volume of $100 \mathrm{mmol}$ Tris- $\mathrm{HCl} \mathrm{l^{-1 }}$ (pH 7.4). The flow-through fraction from the flushings and fluid samples, containing non-heparinbinding substances, was selected for further analysis.

\section{$D E A E$ anion exchange chromatography}

The flow-through fraction from heparin-affinity chromatography of uterine flushings was applied at $2 \mathrm{ml} \mathrm{min}^{-1}$ to a DEAE Sepharose CL-6B column $(2.5 \times 3.5 \mathrm{~cm}$; Pharmacia Biotech) that had been pre-equilibrated with $10 \mathrm{mmol}$ Tris- $\mathrm{HCl}$ $1^{-1}, 0.1 \mathrm{~mol} \mathrm{NaCl} \mathrm{1^{-1 }}(\mathrm{pH} 7.4)$. After application of the sample, the column was washed with $150 \mathrm{ml}$ of equilibration buffer and bound proteins were eluted using a $100 \mathrm{ml}$ gradient of $0.1-2 \mathrm{~mol} \mathrm{NaCl} \mathrm{l}^{-1}$ in $10 \mathrm{mmol}$ Tris- $\mathrm{HCl} \mathrm{l} l^{-1}$ (pH 7.4). The eluate was collected in fractions that were then tested for their ability to stimulate DNA synthesis in quiescent cultures of Balb/c 3T3 cells and to inhibit cellular binding of ${ }^{125}$ I-labelled EGF. Uterine fluid was processed similarly except that the $\mathrm{pH}$ of the sample and buffers was adjusted to 8.5 for anionexchange chromatography to facilitate binding of growth factor to the DEAE-Sepharose column. The active eluate was re-adjusted to $\mathrm{pH} 7.4$ before further anion-exchange chromatography.

\section{EconoPac $Q$ and Mono $Q$ anion exchange chromatography of uterine flushings}

Active fractions from seven, 11 , or 15 individual DEAE purifications of uterine flushings were pooled, diluted three- to fourfold in $20 \mathrm{mmol} \mathrm{Tris-} \mathrm{HCl} \mathrm{l}^{-1}$ ( $\mathrm{pH}$ 7.4), and pumped onto an EconoPac Q column $(0.7 \times 3.6 \mathrm{~cm}$; Bio-Rad Labs) at $2 \mathrm{ml}$ $\min ^{-1}$. The column was then washed with $20 \mathrm{mmol}$ Tris- $\mathrm{HCl}$ $1^{-1}, 0.2 \mathrm{~mol} \mathrm{NaCl}^{-1}$ and developed with a $50 \mathrm{ml}$ gradient of $0.2-1.0 \mathrm{~mol} \mathrm{NaCl}^{-1}$ in $20 \mathrm{mmol}$ Tris- $-\mathrm{HCl}^{-1}$ (pH 7.4) using a fast protein liquid chromatography (FPLC) system (Pharmacia Biotech). Fractions were collected during gradient formation and assayed. Active fractions from each EconoPac $Q$ purification were pooled, diluted sevenfold in $20 \mathrm{mmol}$ Tris$\mathrm{HCl} \mathrm{I}^{-1}$ ( $\mathrm{pH} 7.4$ ), filtered, and applied to a Mono Q HR 5/5 FPLC column (Pharmacia Biotech) that had been equilibrated with $20 \mathrm{mmol}$ Tris- $\mathrm{HCl}^{-1}, 0.1 \mathrm{~mol} \mathrm{NaCl}{ }^{-1}$ (pH 7.4). Bound proteins were eluted using a $40 \mathrm{ml}$ gradient of $0.1-0.75 \mathrm{~mol}$ $\mathrm{NaCl} \mathrm{I}^{-1}$ in $20 \mathrm{mmol}$ Tris- $-\mathrm{HCl} \mathrm{l}^{-1}$ (pH 7.4), and collected into $160250 \mu \mathrm{l}$ fractions. Active fractions were subsequently assayed and subjected to SDS-PAGE and western blotting.

\section{HiLoad $Q$ anion exchange chromatography of uterine fluid}

Active fractions from two individual DEAE purifications of uterine fluid were pooled $(60 \mathrm{ml})$ and diluted to $300 \mathrm{ml}$ with $20 \mathrm{mmol}$ Tris- $-\mathrm{HCl} \mathrm{l}^{-1}$ ( $\mathrm{pH}$ 7.4). The sample was then applied at $4 \mathrm{ml} \mathrm{min} \mathrm{min}^{-1}$ to a HiLoad Q Sepharose FPLC column (10 $\times 26 \mathrm{~cm}$; Pharmacia Biotech) that had been pre-equilibrated with $500 \mathrm{ml} 20 \mathrm{mmol}$ Tris- $\mathrm{HCl} \mathrm{l^{-1 }}, 0.1 \mathrm{~mol} \mathrm{NaCl} \mathrm{1^{-1 }}$ (pH 7.4). The column was washed with $60 \mathrm{ml}$ of equilibration buffer and bound proteins were eluted at $4 \mathrm{ml} \mathrm{min}{ }^{-1}$ using a $320 \mathrm{ml}$ gradient of $0.1-1.0 \mathrm{~mol} \mathrm{NaCl}]^{-1}$ in $20 \mathrm{mmol}$ Tris- $\mathrm{HCl}$ $1^{-1}(\mathrm{pH} 7.4)$. The eluate was collected into $4 \mathrm{ml}$ fractions.

\section{Gel filtration chromatography}

Active fractions from EconoPac $Q$ purification of uterine flushings or from HiLoad $Q$ purification of uterine fluid were 
pooled, passed through a $0.45 \mu \mathrm{m}$ membrane, and concentrated to $0.45-1.5 \mathrm{ml}$ using $5000-10000 \mathrm{M}_{\mathrm{r}}$ cut-off membranes (Amicon, Beverly, MA and Alltech Associates, Deerfield, IL). Each concentrated sample was then filtered through a $0.2 \mu \mathrm{m}$ Acrodisc filter (Gelman Sciences, Ann Arbor, MI) and applied to a G2000 SW gel filtration column $(0.8 \times 30 \mathrm{~cm}, 1000$ $100000 M_{\mathrm{r}}$ fractionation range; TosoHaas, Woburn MA) that was equipped with a SW guard column $(0.8 \times 4 \mathrm{~cm}$; TosoHaas $)$. Proteins were eluted from the column with PBS containing $0.5 \mathrm{~mol} \mathrm{NaCl} 1^{-1}$. The flow rate was $0.5 \mathrm{ml} \mathrm{min}^{-1}$ and fractions of $200 \mu$ l were collected. The column was calibrated with mouse EGF $\left(M_{\mathrm{r}} 6000\right)$, lactalbumin (14 200), trypsin inhibitor (20 100) and ovalbumin (45000).

\section{DNA synthesis and EGF radioreceptor assay}

Column fractions were tested for their ability to stimulate $\left[{ }^{3} \mathrm{H}\right]$ thymidine incorporation into the DNA of confluent quiescent Balb/c $3 \mathrm{~T} 3$ cells that had been cultured in 96-well plates for 7-14 days in Dulbecco's Modified Eagles Medium containing $10 \%$ calf serum $(200 \mu \mathrm{l}$ per well $)$ as described by Besner et al. (1990) and Kim et al. (1995). Aliquots from column fractions were also tested in an EGF radioreceptor assay (RRA) developed in this laboratory using HEC-1-B human endometrial carcinoma cells (Besner et al,, 1992; Kim et al., 1995). Briefly, cells were grown in 48-well plates and then incubated in $150 \mu \mathrm{l}$ of binding medium containing $0.5 \mathrm{ng}{ }^{125}$ I-labelled mouse EGF ml ${ }^{-1}$ ( ${ }^{125} \mathrm{I}$-EGF; DuPont NEN, Boston, MA) for $2 \mathrm{~h}$ at $4^{\circ} \mathrm{C}$ in the presence or absence of the test samples. Nonspecific ${ }^{125}$ I-labelled EGF binding was determined in the presence of $500 \mathrm{ng}$ unlabelled EGF $\mathrm{ml}^{-1}$. DNA synthesis and EGF radioreceptor assays were performed as single determinations for screening column fractions and as single or duplicate determinations for generating dose-response curves, with the data computed as means $\pm \mathrm{SD}$.

\section{SDS-PAGE and western blotting}

Active fractions from Mono $Q$ chromatography were subjected to SDS-PAGE under reducing conditions using 18\% polyacrylamide gels. Successive fractions $(205 \mu \mathrm{l})$ were combined as pairs (410 $\mu \mathrm{l}$ total volume) and diluted to $1.5 \mathrm{ml}$ with $10 \mathrm{mmol}$ Tris $-\mathrm{HCl} 1^{-1}$ (pH 7.5). Samples were desalted and concentrated by passage through $10 \mu \mathrm{l}$ beds of DEAESepharose which were then washed in $10 \mathrm{mmol}$ Tris- $\mathrm{HCl} 1^{-1}$ (pH 7.5) and extracted using $35 \mu$ SDS-PAGE sample buffer. Fifteen microlitres of each sample was loaded into the lanes of duplicate gels. After electrophoresis, proteins in the gels were transferred to nitrocellulose which was then blocked using $10 \mathrm{mmol}$ Tris- $\mathrm{HCl} 1^{-\mathrm{I}}(\mathrm{pH} \mathrm{7.4)}$ containing $0.1 \% \mathrm{BSA}$ and $0.15 \mathrm{~mol} \mathrm{NaCl} \mathrm{l}{ }^{-1}$. Blots were subsequently incubated overnight at $4^{\circ} \mathrm{C}$ in this solution containing either 1:1000 dilution of normal rabbit serum or 1:1000 dilution of a rabbit antiserum raised against $6 \mathrm{kDa}$ recombinant pEGF (Vaughan et al., 1992). This antiserum was kindly donated by K. D. Brown (Babraham Institute, Cambridge, UK). Immune complexes were visualized using alkaline phosphatase-conjugated anti-rabbit $\operatorname{IgG}$ followed by 5-bromo-4-chloro-3-indonyl phosphate and nitroblue

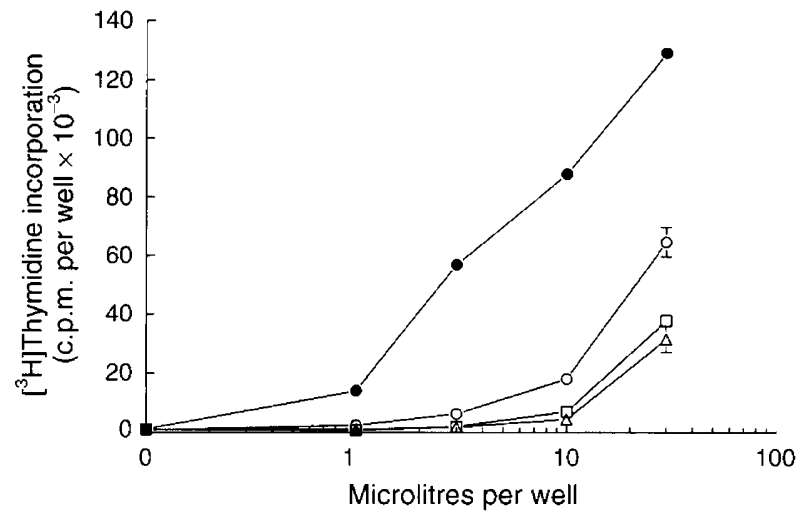

Fig. 1. Stimulation of 3 T 3 cell DNA synthesis by pig uterine flushings or fluid. 3T3 cell DNA synthesis dose-response curves to $(\bullet)$ uterine fluid ( $40 \mathrm{ml}$ total volume from 10 uteri) or ( ) flushings $(500 \mathrm{ml}$ from 20 uteri) before chromatography and after sequential passage of the uterine flushings through (1) a BioRex-70 cation exchange column and (1) a heparin-Sepharose column. Values for $\left[{ }^{3} \mathrm{H}\right]$ thymidine incorporation at each dose are single determinations $(\bullet$ ) or mean \pm SD of duplicate determinations $(,, \ldots)$.

tetrazolium chloride as described (Kim et al., 1995; Brigstock et al., 1996).

\section{Results}

Uterine flushings and fluid stimulated 3T3 cell DNA synthesis in a dose-dependent manner (Fig. 1). To establish if this mitogenic activity was due entirely to platelet-derived growth factor (PDGF), FGFs, HB-EGF or pleiotrophin (all of which are present in uterine luminal flushings (Brigstock et al., 1989, 1996; Kim et al., 1995)), samples were passed through BioRex 70 resin or heparin-Sepharose beads since both of these matrices are known to strongly bind all of these growth factors. Uterine flushings retained mitogenic activity after passage through both types of column (Fig. 1), suggesting that one or more anionic, non-heparin-binding mitogens were present in the partially purified sample. Similar data were obtained for uterine fluid (data not shown). The anionic property of the residual mitogenic activity was then verified by DEAE-anion exchange chromatography. Treatment of the DEAE column with a salt gradient after application of partially purified flushings or fluid resulted in the elution of a peak of mitogenic activity by, respectively, $0.3-0.6 \mathrm{~mol} \mathrm{NaCl}^{-1}$ (Fig. 2a) or $0.3-0.8 \mathrm{~mol}$ $\mathrm{NaCl} \mathrm{I}^{-1}$ (Fig. 2b). EGF is a highly anionic growth factor that stimulates 3T3 cell mitosis, does not bind to heparin (Besner et al., 1990), and is present in the uterine tract of pigs (Vaughan et al., 1992; Diehl et al., 1994; Kennedy et al., 1994); therefore, an EGF radioreceptor assay of fractions from the DEAE column was performed using HEC-1-B cells. A competitor of ${ }^{125} \mathrm{I}-$ labelled EGF binding was eluted from DEAE columns over the same $\mathrm{NaCl}$ concentration range as $3 \mathrm{~T} 3$ cell mitogenic activity (Fig. 2a, b).

The anionic growth factor from uterine flushings was further purified by subjecting active fractions from multiple DEAESepharose column purifications to EconoPac $\mathrm{Q}$ anion exchange chromatography. A typical chromatogram is shown (Fig. 3a), 
(a)

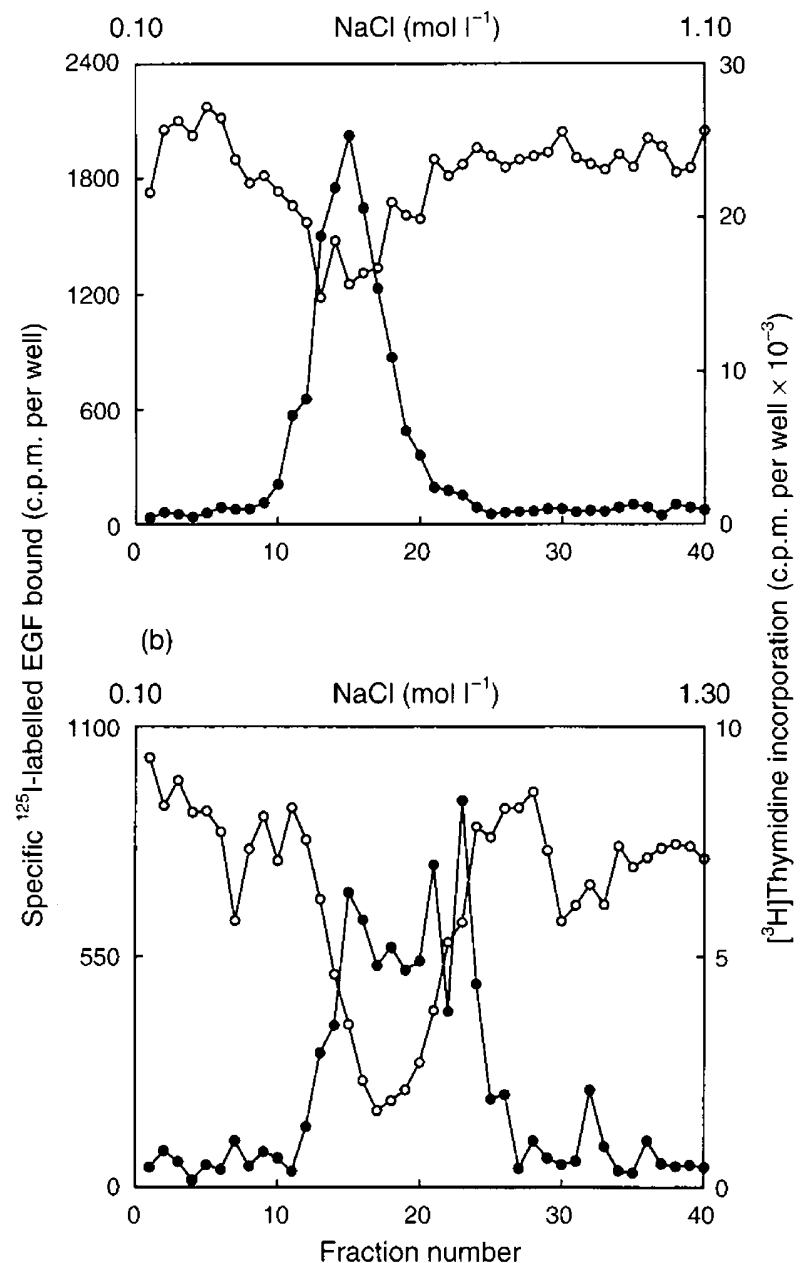

Fig. 2. DEAE-anion exchange chromatography of pig uterine flushings and fluid. (a) Uterine flushings $(900 \mathrm{ml})$ from 29 pigs were subjected to BioRex-70 and heparin-affinity chromatography. The flow-through fraction was then applied at $2 \mathrm{mi} \mathrm{min}^{-1}$ to a DEAESepharose column that was then washed with $150 \mathrm{ml} 10 \mathrm{mmol}$

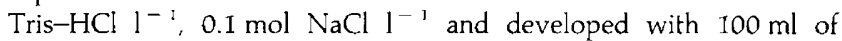
$0.1-2 \mathrm{~mol} \mathrm{NaCl} 1^{-1}$ in $10 \mathrm{mmol}$ Tris- $\mathrm{HCl}$ ( $\mathrm{pH} \mathrm{7.4).} \mathrm{Seventy-five}$ fractions (approx $1.3 \mathrm{ml}$ each) were collected and tested at $7 \mu \mathrm{l}$ per well for their stimulation of $3 \mathrm{~T} 3$ cell DNA synthesis $(\bullet)$ and at $15 \mu \mathrm{l}$ per well for their inhibition of ${ }^{125}$ I-labelled epidermal growth factor (EGF) binding (). (b) Filtered uterine fluid $(160 \mathrm{ml})$ was diluted to $1.5 \mathrm{I}$ with $10 \mathrm{mmol}$ Tris- $\mathrm{HCl} \mathrm{l} 1^{-1}, 0.1 \mathrm{~mol} \mathrm{NaCl} l^{-1}(\mathrm{pH} \mathrm{7.4)}$ and passed through a heparin-affinity column. The flow-through fraction was then applied to a DEAE-Sepharose column that was washed and developed as described in (a) above. Sixty-two fractions (approximately $1.6 \mathrm{ml}$ each) were collected and tested at $10 \mu \mathrm{l}$ per well in the $3 \mathrm{~T} 3$ cell DNA synthesis assay $(\bullet)$ and in the ${ }^{125}$ I-labelled EGF radioreceptor assay ().

and demonstrates the elution of $3 \mathrm{~T} 3$ cell mitogenic activity as two peaks, one by $0.2-0.3 \mathrm{~mol} \mathrm{NaCl}^{-1}$ and a second, smaller peak by $0.35-0.4 \mathrm{~mol} \mathrm{NaCl}^{-1}$. Since active fractions from the first peak also inhibited ${ }^{125}$ I-labelled EGF binding (Fig. 3a), they were concentrated and further purified by gel filtration chromatography. Peaks of mitogenic activity and ${ }^{125}$ I-labelled EGF competition co-eluted in fractions corresponding to $M_{\mathrm{r}} 45000$ (Fig. 3b). No evidence for a $6 \mathrm{kDa}$ form of EGF was obtained.
The presence of high molecular mass forms of EGF in the first EconoPac $Q$ peak was verified by further purification of the corresponding fractions from a different EconoPac $Q$ purification by Mono $Q$ chromatography and analysis by SDS-PAGE and western blotting. Mitogenic activity was eluted from the Mono $\mathrm{Q}$ column by $0.3 \mathrm{~mol} \mathrm{NaCl} \mathrm{l}^{-1}$ (Fig. 3c) and was correlated with the presence of several proteins of $M_{\mathrm{r}} \sim 25000$ that were detected by a pEGF-specific rabbit antiserum but not by normal rabbit serum (Fig. 3c, inset). Immunoreactive $\mathrm{EGF}$ proteins of $6 \mathrm{kDa}$ were not detectable in the active fractions (Fig. 3c). Recombinant $6 \mathrm{kDa}$ mouse and human EGF were subjected to SDS-PAGE under identical conditions to ensure that $6 \mathrm{kDa}$ EGF migrated as predicted under the SDS-PAGE conditions used in this study, with the result that they both migrated close to a $6.5 \mathrm{kDa}$ aprotinin standard (data not shown). Further analysis of the second mitogenic peak from EconoPac $Q$ chromatography of uterine flushings was not possible in view of the low amounts of activity that were recovered (Fig. $3 a$ ). In addition, western blot analysis of the gel filtration fractions of high molecular mass were inconclusive, also owing to low recoveries of the bioactive protein(s).

Uterine fluid was of higher specific activity than uterine flushings (Fig. 1) and contained a similar growth factor activity (Fig. 2); therefore, subsequent experiments were conducted with fluid samples. When DEAE-purified uterine fluid was subjected to large-scale HiLoad $Q$ anion exchange chromatography, two mitogenic peaks were eluted from the column, both of which were correlated with individual peaks of competition for ${ }^{125}$ I-labelled EGF binding (Fig. 4a). These peaks, which were eluted by $0.4 \mathrm{~mol} \mathrm{NaCl}^{-1}$ (Peak I) and $0.45 \mathrm{~mol} \mathrm{NaCl} \mathrm{l}^{-1}$ (Peak 2), were consistently observed in several HiLoad $Q$ purifications. Subsequent analysis of Peak $I$ by gel filtration under dissociating, non-reducing conditions showed that its mitogenic and ${ }^{125}$ I-labelled EGF-competing properties co-eluted in fractions corresponding to $M_{\mathrm{r}} 3000-6000$ (Fig. $4 \mathrm{~b})$. However, under the same conditions, Peak 2 was separated into moieties of two molecular masses corresponding to $M_{\mathrm{r}} 3000-6000$ and $40000-70000$ (Fig. 4c). Although further purification of these various EGF-like proteins was acheived using $C_{8}$ reverse-phase high performance liquid chromatography (data not shown), their structural characterization was unsuccessful due to the continued presence of contaminating proteins.

\section{Discussion}

Although EGF-like factors have been detected in uterine luminal fluids of mice and rats by radioreceptor assay or radioimmunoassay (Imai 1982; DiAugustine et al., 1988), the molecular size of the secreted EGF protein(s) has not been reported for these species and has been hampered by the lack of fluid available for analysis. A uterine secretory EGF-like factor in pigs was first demonstrated by Simmen et al. (1988), who showed that the mitogenic activity of uterine flushings was partially decreased by an antiserum to mouse EGF. Although immunoreactive EGF has since been detected in the pig uterus, oviduct and uterine flushings by homologous and heterologous radioimmunoassays or immunohistochemistry 
(Vaughan et al., 1992; Diehl et al., 1994; Kennedy et al., 1994; Swanchara et al., 1995), these reports have not addressed qualitative aspects of the uterine luminal EGF protein. While our data confirm the presence of non-heparin-binding, anionic, EGF-like growth factors in uterine flushings and fluid, they further demonstrate their occurrence as high molecular mass as well as $6 \mathrm{kDa}$ proteins. The structural relationship between the $45 \mathrm{kDa}$ biologically active protein observed by gel filtration and the $25 \mathrm{kDa}$ immunoreactive EGF proteins observed by

(a)

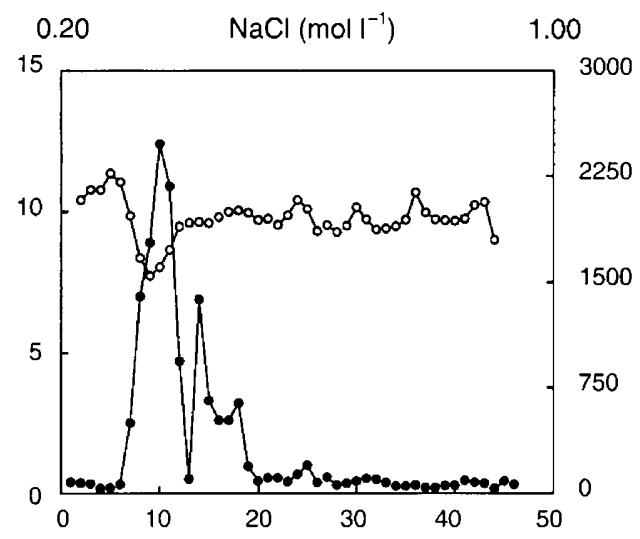

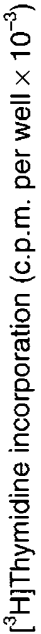

(b)

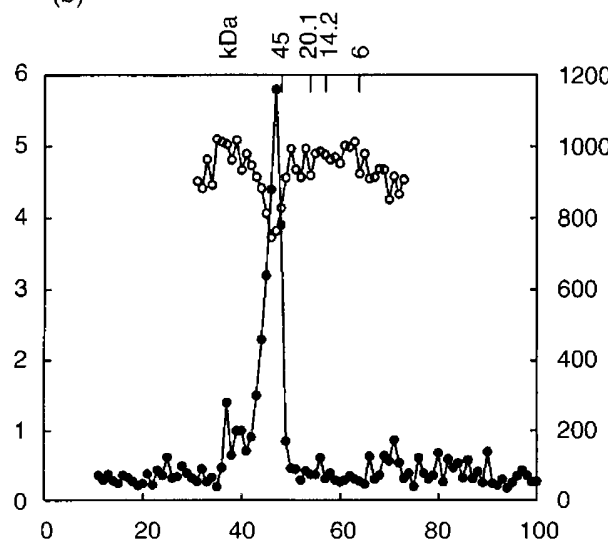

(c)

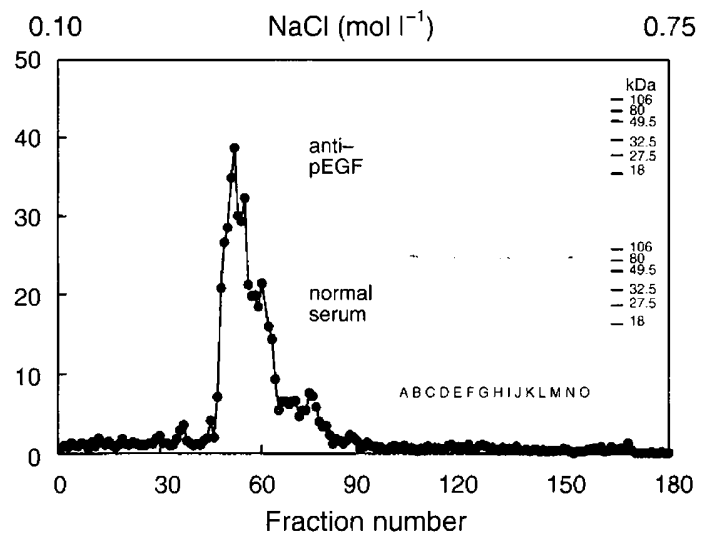

SDS-PAGE in uterine flushings has not yet been established. For example, (i) the different molecular masses may be the result of the same molecule migrating at different rates under the non-reducing dissociating conditions used in gel filtration as opposed to the reducing and denaturing conditions used in SDS-PAGE; (ii) the gel filtration data may reflect the presence of a carrier protein for the $25 \mathrm{kDa}$ form of EGF that was dissociated under the conditions of SDS-PAGE or (iii) distinct molecular forms of EGF may have been detected by each technique. Whatever the explanation, the data show that uterine secretions contain biologically active forms of EGF that are of appreciably higher molecular mass than mature EGF.

Since the 3-6 kDa factor in uterine fluid was not characterized by western blotting, the possibility that it is a low molecular mass ligand for the EGF receptor (EGF-R) that is distinct from EGF itself cannot be excluded. One such molecule would be TGF- $\alpha$ which is produced by the pig uterus (Kennedy et al., 1994) and is of $M_{\mathrm{r}} 6000$ in its mature form (Carpenter and Wahl, 1991). Alternatively, the reactivity of the high molecular mass proteins with a highly specific pig EGF antiserum (Vaughan et al., 1992) coupled with their lack of heparin-binding supports the notion that these are genuine forms of EGF rather than other members of the EGF family such as TGF- $\alpha$, HB-EGF or amphiregulin. Although the basis for the mass of these proteins requires further study, possibilities such as complexes of EGF with itself or other proteins seem unlikely given the dissociating or denaturing conditions used in gel filtration or SDS-PAGE. However, an alternative

Fig. 3. Characterization of anionic growth factors in pig uterine flushings. (a) Active fractions from 15 individual DEAE purifications of uterine flushings (approximately $12 \mathrm{I}$ starting material from 383 pigs) were pooled ( $200 \mathrm{ml}$ total volume), diluted to $800 \mathrm{ml}$ with $20 \mathrm{mmol}$ Tris- $\mathrm{HCl} \mathrm{1^{-1 }}(\mathrm{pH} 7.4)$, and applied as two $400 \mathrm{ml}$ samples to an EconoPac $Q$ column. In each run, the column was washed with $20 \mathrm{mmol}_{\text {Tris- }} \mathrm{HCl} \mathrm{l}^{-1}, 0.2 \mathrm{~mol} \mathrm{NaCl} \mathrm{l^{-1 }}(\mathrm{pH} \mathrm{7.4)}$ and developed with a $50 \mathrm{ml}$ gradient of $0.2-1.0 \mathrm{~mol} \mathrm{NaCl} \mathrm{^{-1 }}$. Fifty fractions ( $1 \mathrm{ml}$ each) were collected and tested at $7 \mu \mathrm{l}$ per well in the 3T3 cell DNA synthesis assay $(\bullet)$ and at $15 \mu \mathrm{l}$ per well in the ${ }^{125} \mathrm{I}$-labelied epidermal growth factor (EGF) binding assay $\left(^{-}\right)$. (b) Fractions 7-12 from the two EconoPac $\mathrm{Q}$ runs described in (a) above were pooled ( $12 \mathrm{ml}$ ), and concentrated to $450 \mu \mathrm{l}$ using a $5000-M_{\mathrm{r}}$ cut-off membrane. The sample was then injected on to a G2000 SW column that was then washed with PBS/0.5 mol NaCl $l^{-1}$ at $0.5 \mathrm{ml} \mathrm{min}^{-1}$. One hundred and three fractions $(200 \mu \mathrm{l}$ each) were collected and tested at $5 \mu \mathrm{l}$ per well for stimulation of 3T3 cell DNA synthesis $(\bullet)$ and at $10 \mu \mathrm{l}$ per well for inhibition of ${ }^{125}$ I-labelled EGF binding (*). (c) Fractions 7-12 from two EconoPac $Q$ purifications, obtained from 18 samples of uterine flushings as described in (a) above, were pooled, diluted and applied to a Mono Q FPLC column that was subsequently washed with $0.1 \mathrm{~mol} \mathrm{NaCl}^{-1}$ in $20 \mathrm{mmol}$ Tris- $\mathrm{HCl} \mathrm{l}^{-1}(\mathrm{pH} \mathrm{7.4).} \mathrm{Bound}$ proteins were then eluted at $0.5 \mathrm{ml} \mathrm{min}{ }^{-1}$ using a $40 \mathrm{ml}$ gradient of $0.1-0.75 \mathrm{~mol} \mathrm{NaCl} \mathrm{l}^{-\mathrm{I}}$ in $20 \mathrm{mmol}$ Tris- $\mathrm{HCl} \mathrm{l^{-1 }}$ (pH 7.4) and collected into fractions of $250 \mu \mathrm{l}$. The figure shows the 3T3 cell mitogenic activity of the fractions when assayed at $15 \mu \mathrm{l}$ per well. The inset shows a western blot of paired mitogenic fractions using 1:1000 dilutions of pig EGF antiserum or normal rabbit serum. Lanes $A$ and $K$ contained pre-stained molecular mass standards. Lanes B, C, D, E, F, G, $\mathrm{H}, \mathrm{I}, \mathrm{J}, \mathrm{L}, \mathrm{M}, \mathrm{N}$ and $\mathrm{O}$ contained fractions $40-41,42-43,44-45$, $46-47,48-49,50-51,52-53,54-55,56-57,58-59,60-61,62-63$ and $64-65$, respectively. 
explanation is the incomplete processing of the EGF precursor. While the pig EGF precursor has been only partially characterized (Pascall et al., 1991), that of other species is initially synthesized as a $\sim 1200$-residue transmembrane protein from which mature $6 \mathrm{kDa}$ EGF is released by extracellular proteolytic cleavage. Despite this well characterized processing

(a)

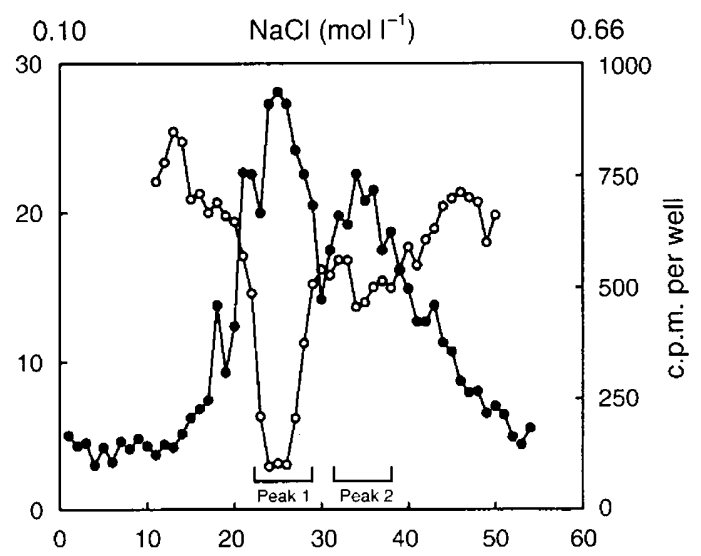

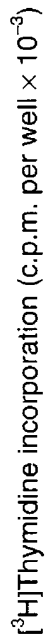

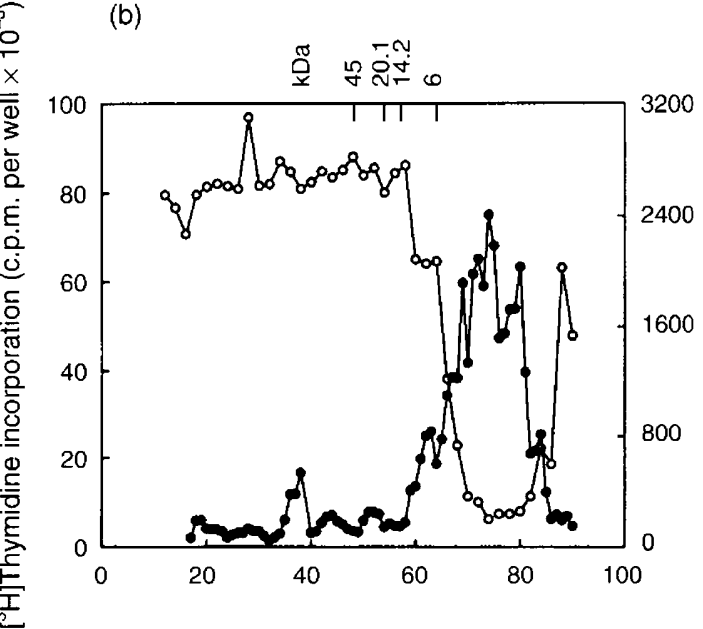

(c)

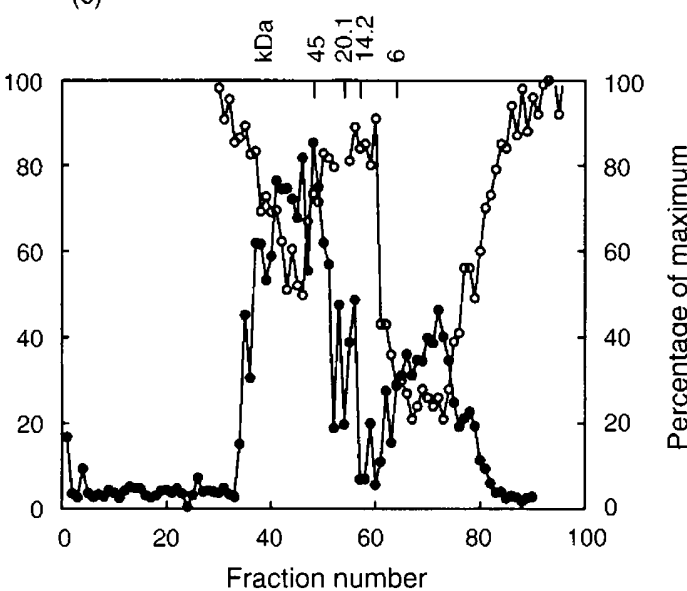

mechanism, size heterogeneity has nevertheless been documented for human and rat EGF. Human urine was shown to contain a high molecular mass form of EGF that contained $28 \mathrm{kDa}$ and $33 \mathrm{kDa}$ components after SDS-PAGE under reducing conditions (Hirata and Orth, 1979). Analysis of multiple human body fluids by gel filtration and radioimmunoassay further showed that urine, milk, seminal plasma, saliva, tears, amniotic fluid and breast sweat contained high molecular mass forms of EGF of $M_{\mathrm{r}} 20000,70000,150000$ and $\geq 300000$ (Pesonen ef al., 1987). Whereas the N-terminus of mature 6 $\mathrm{kDa}$ human EGF commences at Asn971 of the EGF precursor, structural characterization of human urinary $30-33 \mathrm{kDa}$ EGF proteins showed that their $\mathrm{N}$-termini commenced at Met828 or Val829 of the precursor molecule (Mount et al., 1987; Tsukumo et al., 1987). Similarly by comparison with the mouse EGF precursor, the $\mathrm{N}$-terminus of a biologically active $45 \mathrm{kDa}$ form of rat urinary EGF was shown to start at Asn837 (Nexo et al, 1990). More recently human milk and urine have been shown by western blotting to contain a $160-170 \mathrm{kDa}$ form of the EGF precursor that was biologically active as shown by its ability to stimulate tyrosine phosphorylation of the EGF receptor (Mroczkowski and Reich, 1993). The secreted $170 \mathrm{kDa}$ EGF precursor was shown to bind to heparin (Mroczkowski and Reich, 1993), whereas $6 \mathrm{kDa}$ EGF (Besner et al., 1990) and the EGF proteins of high molecular mass detected in this study do not. In addition, $33 \mathrm{kDa}$ urinary human EGF had $26 \%$ of the receptor-binding activity as $6 \mathrm{kDa}$ human EGF (Hirata and Orth, 1979). These data suggest that the additional amino acid sequence in EGF molecules of high molecular mass may serve to regulate their bioavailability or biological activity. Although the factors that lead to production of high molecular mass forms of EGF in the uterus have yet to be defined, it may be relevant that the pig uterus produces protease inhibitors (Fazleabas et al., 1982; Roberts and Bazer, 1988) that may result in incomplete processing of the EGF precursor.

The presence and binding properties of pig endometrial EGF-R were initially described by Zhang et al. (1992a). More recently, RT-PCR was used to show that mRNAs encoding EGF and EGF-R are present in pig endometrium on days 4,13 , 15 and 20 of the oestrous cycle and on days 10,12, 14, 18 and 22 of pregnancy (Kennedy et al., 1994). In addition, using the same anti-pEGF antiserum with which we performed western

Fig. 4. Characterization of anionic growth factors in pig uterine fluid (a) Active fractions from individual DEAE-Sepharose purifications of two uterine fluid samples $(100 \mathrm{ml}$ fluid each) were pooled, diluted 1:6 in $20 \mathrm{mmol}$ Tris- $\mathrm{HCl} \mathrm{I}^{-1}$ ( $\mathrm{pH} \mathrm{7.4)} \mathrm{(300} \mathrm{ml} \mathrm{final} \mathrm{volume),} \mathrm{and} \mathrm{applied}$ to a HiLoad Q FPLC column at $4 \mathrm{ml} \mathrm{min}^{-1}$. The column was washed with $60 \mathrm{ml}$ of $20 \mathrm{mmol}$ Tris- $\mathrm{HCl} \mathrm{l}{ }^{-1}, 0.1 \mathrm{~mol} \mathrm{NaCl} \mathrm{l}^{-1}(\mathrm{pH} \mathrm{7.4)}$ and bound proteins were eluted at $4 \mathrm{ml} \mathrm{min}{ }^{-1}$ using a $320 \mathrm{ml}$ gradient of $0.1-1.0 \mathrm{~mol} \mathrm{NaCl}^{-1}$ in $20 \mathrm{mmol}$ Tris-HCl $1^{-1}$ (pH 7.4). Ninety-five fractions $(4 \mathrm{ml}$ each) were collected. Selected fractions were tested at $15 \mu \mathrm{l}$ per well for their stimulation of 3 T3 cell DNA synthesis $(\bullet)$. The ${ }^{125}$ I-labelled epidermal growth factor (EGF) binding data (o) were generated from a comparable run in which fractions were assayed at $10 \mu \mathrm{l}$ per well. Active fractions from (b) Peak 1 or (c) Peak 2 from six HiLoad $Q$ purifications were pooled, concentrated, and applied to a G2000 SW gel filtration column as described in Fig. 3b. Fractions were tested at $3 \mu \mathrm{l}$ per well in the DNA synthesis (*) and EGF radioreceptor ( ) assays. 
blotting, these investigators demonstrated that EGF immunoreactivity was detected primarily in the glandular epithelial cells of endometrium from pregnant and non-pregnant animals (Kennedy et al., 1994). Moreover, their immunohistochemical data provided evidence for a membrane-associated form of EGF, with apparently higher amounts of EGF on the luminal surfaces. Although the EGF-R and its ligands are steroidally regulated in the uteri of other species (Brigstock, 1991), further research is required to clarify the role of oestrogen and progesterone in regulating mRNAs encoding EGF and EGF-R and protein content in the pig uterus. In addition, since our studies were conducted using uterine fluids and flushings from prepubertal pigs as well as pigs at random stages of the cycle, it is yet to be established whether the production of high molecular mass forms of EGF is associated with the stage of maturity of the uterus, or stage of the oestrous cycle or pregnancy. Although it has been inferred that the pattern of mRNA expression of EGF-R and EGF does not support a primary role for these factors in early pig embryonic development (Kennedy et al., 1994), the results reported here suggest that further studies are required at the protein level to address this point. While this report focussed on non-pregnant animals to prevent contamination of uterine fluids by embryo-derived EGF, embryonic development and survival may be regulated by extrinsic uterine EGF, either by its secretion into the uterine lumen or by its localization at the implantation site (Brigstock et al., 1989, 1994; Pollard, 1990; Brigstock, 1991; Pollard et al., 1991; Simmen and Simmen, 1991; Cullingford and Pollard, 1994). EGF-R in extra-embryonic and placental membranes (Corps et al., 1990, Zhang et al., 1992b) are possible targets for uterine secretory EGF, and this role for uterine secretory EGF may persist for relatively long periods in the pig as this species exhibits non-invasive placentation (Roberts and Bazer, 1988).

In summary, the data presented here suggest that uterine fluids contain variably processed forms of the EGF precursor that bind and activate the EGF receptor. Since body fluids have been proposed as an important reservoir and delivery system for EGF (Carpenter and Wahl, 1991), further biological and structural characterization of uterine secretory EGF of high molecular mass and $6 \mathrm{kDa}$ EGF should prove fruitful for understanding their respective functions in the female reproductive tract.

D. R. Brigstock was supported by an Ohio State University Seed Grant and by the Children's Hospital Research Foundation (020-871), the Bremer Foundation, the Department of Surgery Medical Research and Development Fund, Surgical Research, Inc., The Milheim Foundation for Cancer Research (93-03), The American Cancer Society (Ohio Affiliate) and the National Institutes of Health (HD 30334). N. H. Ismail was supported by a Children's Hospital Firefighters Scholarship, R. K. Vegunta by the E. Thomas Boles Scholarship in Pediatric Surgery, and G. Y. Kim by a Samuel J. Roessler Research Scholarship. We thank K. D. Brown for supplying the antiserum to pig EGF.

\section{References}

Besner GE, Higashiyama S and Klagsbrun M (1990) Isolation and characterization of a macrophage-derived heparin-binding growth factor Cell Regulation $1811-819$

Besner GE, Whelton D, Crissman-Combs MA, Steffen CL, Kim GY and Brigstock DR (1992) Interaction of heparin-binding EGF-like growth factor (HB-EGF) with the epidermal growth factor receptor: modulation by heparin, heparinase, or synthetic heparin-binding HB-EGF peptides Growth Factors 7 289-296

Brigstock DR (1991) Polypeptide growth factors in the uterus: steroidal regulation and biological actions Balliere's Clinical Endocrinology and Metrobolism 5 791-808

Brigstock DR, Heap RB and Brown KD (1989) Polypeptide growth factors in uterine tissues and secretions Journal of Reproduction and Fertility 85 747-758

Brigstock DR, Heap RB, Barker PJ and Brown KD (1990) Purification and characterization of heparin-binding growth factors from porcine uterus Biochemical Journal 266 273-282

Brigstock DR, Kim GY, Steffen CL and Ismail NY (1994) Control of embryonic development by uterine growth factors and cytokines Assisted Reproductive Technology/Andrology 6 252-263

Brigstock DR, Kim GY and Steffen CL (1996) Pig uterine fluid contains the developmentally-regulated neurotrophic factor, pleiotrophin Journal of Endocrinology 148 103-111

Carpenter G and Wahl MI (1991) The epidermal growth factor family. In Peptide Growth Factors and their Receptors Vol. I pp 69-171 Eds MB Sporn and AB Roberts. Springer-Verlag, New York

Corps AN, Brigstock DR, Littlewood CJ and Brown KD (1990) Receptors for epidermal growth factor and insulin-like growth factor-I on preimplantation trophoderm of the pig Development 110 221-227

Cullingford TE and Pollard JW (1994) Growth factors as mediators of sex steroid action in the uterus during its preparation for implantation. In Proto-Oncogenes and Growth Factors in Steroid Hormone Induced Growth and Differentiation pp 13-30 Eds SA Khan and GM Stancel. CRC Press, Ann Arbor.

DiAugustine RP, Petrusz P, Bell GI, Brown CF, Korach KS, McLachlan JA and Teng CT (1988) Influence of estrogens on mouse uterine epidermal growth factor precursor protein and messenger ribonucleic acid Endocrinology $\mathbf{1 2 2}$ $2355-2363$

Diehl JR, Henricks DM and Gray SL (1994) EGF and IGF-I in the uterine and oviductal fluids of pregnant and non-pregnant pigs from day 10 to day 18 Biology of Reproduction 50 (Supplement I) A272

Fazleabas AT, Bazer FW and Roberts RM (1982) Purification and properties of a progesterone-induced plasmin/trypsin inhibitor from uterine secretions of pigs and its immunocytochemical localization in the pregnant uterus foumal of Biological Chemistry 257 6886-6897

Flaumenhaft R and Rifkin DB (1992) The extracellular regulation of growth factor action Molecular Biology of the Cell 3 1057-1065

Hirata Y and Orth DN (I979) Epidermal growth factor (urogastrone) in human fluids: size heterogeneity Journal of Clinical Endocrinology and Metabolism 48 673-679

Imai Y (1982) Epidermal growth factor in rat uterine luminal fluid Endocrinology 110 (Supplement) A331

Kennedy TG, Brown KD and Vaughan T] (1994) Expression of the genes for the epidermal growth factor receptor and its ligands in porcine oviduct and endometrium Biology of Reproduction 50 751-756

Kim GY, Besner GE, Steffen CL, McCarthy DW, Downing MT, Luquette MH, Abad MS and Brigstock DR (1995) Purification of heparin-binding EGF-like growth factor from pig uterine luminal flushings and its production by endometrial tissues Biology of Reproduction 52 561-571

Letcher R, Simmen RCM, Bazer FW and Simmen FA (1989) Insulin-like growth factor-I expression during early conceptus development in the pig Biology of Reproduction 41 1143-1151

Mount CD, Lukas TJ and Orth DN (1987) Characterization of a high-molecular weight form of epidermal growth factor in an extract of human urine Archives of Biochemistry and Biophysics 255 1-7

Mroczkowski B and Reich M (1993) Identification of biologically active epidermal growth factor precursor in human fluids and secretions Endocrinology 132 417-425

Nexo E, Jorgenson PE, Thim L and Roepstorff P (1990) Purification and characterization of a low and a high molecular weight form of epidermal growth factor from rat urine Biochimica et Biophysica Acta 1037 388-393

Ogasawara M, Karey KP, Marquardt H and Sirbasku DA (1989) Identification and purification of truncated insulin-like growth factor from porcine uterus: evidence for high biological potency Biochemistry 28 2710-2721

Pascall JC, Jones DSC, Doel SM, Clements JM, Hunter M, Fallon T, Edwards M and Brown KD (1991) Cloning and characterization of a gene encoding pig epidermal growth factor Joumal of Molecular Endocrinology 6 63-70 
Pesonen K, Viinikka L, Kosimies A, Banks AR, Nicolson M and Perheentupa J (1987) Size heterogeneity of epidermal growth factor in human body fluids Life Sciences $402489-2494$

Pollard JW (1990) Regulation of polypeptide growth factor synthesis and growth factor-related gene expression in the rat and mouse uterus before and during implantation Journal of Reproduction and Fertility 88 721-731

Pollard JW, Pampfer S, Daiter E and Arceci RJ (1991) Cytokines at the maternal fetal interface: colony-stimulating factor- 1 as a paradigm for the maternal regulation of pregnancy. In Uterine and Embryonic Factors in Early Pregnancy pp 107-118 Eds JF Strauss III and CR Lyttle. Plenum Press, New York

Prigent SA and Lemoine NR (1992) The Type 1 (EGFR-related) family of growth factor receptors and their ligands Progress in Growth Factor Research 4 I-24

Roberts RM and Bazer FW (1988) The functions of uterine secretions Journal of Reproduction and Fertility $\mathbf{8 2} 875-892$

Simmen FA and Simmen RCM (1991) Peptide growth factors and proto-oncogenes in mammalian conceptus development Biology of Reproduction 44 1-5

Simmen RCM, Ko Y, Liu XH, Wilde MH, Pope WF and Simmen FA (1988) A uterine cell mitogen distinct from epidermal growth factor in porcine uterine fluids: characterization and partial purification Biology of Reproduction 38 551-561

Simmen RCM, Simmen FA, Hofig A, Farmer SJ and Bazer FW (1990) Hormonal regulation of insulin-like growth factor gene expression in the pig uterus Endocrinology 127 2166-2174
Simmen FA, Simmen RCM, Geisert RD, Martinat-Botte F, Bazer FW and Terqui M (1992) Differential expression, during the estrous cycle and pre- and post-implantation conceptus development, of messenger ribonucleic acids encoding components of the pig insulin-like growth factor system Endocrinology 130 1547-1556

Swanchara KW, Henricks DM, Birrenkott GP, Bodine AB and Richardson ME (1995) Expression of epidermal growth factor (EGF) and the EGF receptor in the porcine oviduct Biology of Reproduction 53 911-922

Tavakkol A, Simmen FA and Simmen RCM (1988) Porcine insulin-like growth factor-I (pIGF-I): complementary deoxyribonucleic acid cloning and uterine expression of messenger ribonucleic acid encoding evolutionarily conserved IGF-I peptides Molecular Endocrinology 2 674-68I

Tsukumo K, Nakamura H and Sakamoto S (1987) Purification and characterization of high molecular weight human epidermal growth factor from human urine Biochemical and Biophysical Research Communications 145 126-133

Vaughan TJ, Littlewood CJ, Pascall JC, and Brown KD (1992) Epidermal growth factor concentrations in pig tissues and body fluids measured using a homologous radioimmunoassay Journal of Endocrinology 135 77-83

Zhang K, Krause M and Davis DL (1992a) Epidermal growth factor receptors in porcine emdometrium: binding characteristics and the regulation of prostaglandin $\mathrm{E}$ and $\mathrm{F}_{2 \mu}$ production Biology of Reproduction 46 932-936

Zhang Y, Paria BC, Dey SK and Davis DL (1992b) Characterization of the epidermal growth factor receptor in preimplantation pig conceptuses Developmental Biology $151617-621$ 